\title{
Enantiomers of the Muscarinic Antagonist 1-Cyclohexyl-1-(4-fluorophenyl)-4- piperidino-1-butanol (p-Fluoro-hexahydro-difenidol): Synthesis, Absolute Configuration, and Enantiomeric Purity
}

\author{
Carsten Strohmann", Sigurd Bauerecker ${ }^{b}$, Heiko K. Cammenga ${ }^{b}$, Peter G. Jones ${ }^{c}$, Ernst Mutschlerd, Günter Lambrecht ${ }^{d}$,
} and Reinhold Tacke*a

Institut für Anorganische Chemie der Universität Karlsruhe ${ }^{2}$, Engesserstraße, Geb. 30.45, D-7500 Karlsruhe 1

Institut für Physikalische und Theoretische Chemie der Technischen Universität Braunschweig ${ }^{b}$, Hans-Sommer-Straße 10, D-3300 Braunschweig

Institut für Anorganische und Analytische Chemie der Technischen Universität Braunschweig ${ }^{c}$, Hagenring 30, D-3300 Braunschweig

Pharmakologisches Institut für Naturwissenschaftler der Universität Frankfurt ${ }^{d}$, Theodor-Stern-Kai 7, Geb. 75A, D-6000 Frankfurt/Main

Received December 12, 1990

Key Words: Difenidol, p-fluoro-hexahydro-, enantiomers of / Muscarinic receptors, subtypes of

The enantiomers of the antimuscarinic agent 1-cyclohexyl-1(4-fluorophenyl)-4-piperidino-1-butanol $[(R)$ - and $(S)$-p-fluorohexahydro-difenidol $[(R)$ - and $(S)-2 \mathrm{a}]$ and their methiodides $(R)$ 3 and (S)-3 were prepared with high enantiomeric purity. $(R)$ 2a and (S)-2a (isolated as hydrochlorides) were obtained by catalytic hydrogenation ( $\mathrm{Pd} / \mathrm{C}$ contact) of the corresponding enantiomers of 1-cyclohexyl-1-(4-fluorophenyl)-4-piperidino2-butyn-1-ol $[(R)$ - and (S)-4]. Reaction of $(R)$-2a and (S)-2a with methyl iodide led to $(R)-3$ and $(S)-3$, respectively. The unsaturated precursors $(R)$ - and $(S)-4$ (enantiomeric purity $\geqslant 99.80$ and $\geqslant 99.94 \%$ e.e.; calorimetric analysis) were prepared by res- olution of rac-4 [available from $4-\mathrm{FC}_{6} \mathrm{H}_{4} \mathrm{C}(\mathrm{O}) \mathrm{C}_{6} \mathrm{H}_{14}$ by reaction with $\mathrm{LiC} \equiv \mathrm{CCH}_{2} \mathrm{NC}_{5} \mathrm{H}_{10}$ ] using $(R)$ - and $(S)$-mandelic acid as resolving agents. The absolute configurations of the $(R)$ and $(S)$ enantiomers of $2 a, 3$, and 4 were determined by an X-ray crystal-structure analysis of $(S)-5$, the methiodide of $(S)-4$. $(R)$ $2 \mathrm{a}$ and $(R)-3$ exhibit a higher affinity for muscarinic $M 1, M 2$, M3, and M4 receptors (by up to two orders of magnitude) than their corresponding antipodes $(S)-2 \mathrm{a}$ and $(S)-3$, the degree of stereoselectivity depending on the receptor subtype involved. $(R)-2$ a represents a useful tool for muscarinic receptor research (affinity profile: $\mathrm{M} 1 \approx \mathrm{M} 3 \approx \mathrm{M} 4>\mathrm{M} 2$ ).
The racemic silanols hexahydro-sila-difenidol $(\mathrm{rac}-1 \mathrm{~b})$ and $p$-fluoro-hexahydro-sila-difenidol ( $r a c-2 b)$, both developed in our laboratories, are commercially available antimuscarinic agents that are used as tools in experimental pharmacology and physiology for the classification of muscarinic receptor subtypes ${ }^{1,22}$. The racemic carbon analogs hexahydro-difenidol ( $\mathrm{rac}-1 \mathrm{a})$ and $\mathrm{p}$-fluoro-hexahydro-difenidol (rac-2a) are also potent and selective muscarinic antagonists but were found to be somewhat less selective in functional studies than the silicon compounds rac- $1 \mathrm{~b}$ and rac$\mathbf{2 b}^{2,2,2 b}$. Because of its receptor selectivity and stereoselective antimuscarinic activity, $(R)$-hexahydro-difenidol $[(R)-1 \mathrm{a}]$ also proved to be a valuable tool in muscarinic receptor research ${ }^{2,3)}$. We were therefore interested in the antimuscarinic properties of the enantiomers of the p-fluoro derivative $2 \mathbf{a}$. In this paper we report on the synthesis and properties of the pure enantiomers of $p$-fluoro-hexahydro-difenidol $[(R)-2 \mathrm{a}$ and $(S)-2 \mathrm{a}]$ and their methiodides $(R)-3$ and (S)-3.

The enantiomers of $p$-fluoro-hexahydro-difenidol (2a) were prepared from the unsaturated precursor $r a c-4$ which was synthesized by reaction of cyclohexyl 4-fluorophenyl ketone with 3-piperidino-1-propyn-1-yl-lithium, followed by an aqueous workup. Then the enantiomers of 4 were sepa-

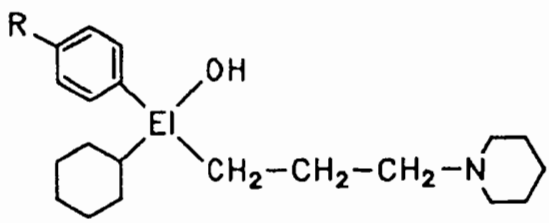

\begin{tabular}{c|cccc} 
& 10 & $1 b$ & 20 & $2 b$ \\
\hline$E I$ & $C$ & $S i$ & $C$ & $S i$ \\
$R$ & $H$ & $H$ & $F$ & $F$
\end{tabular}

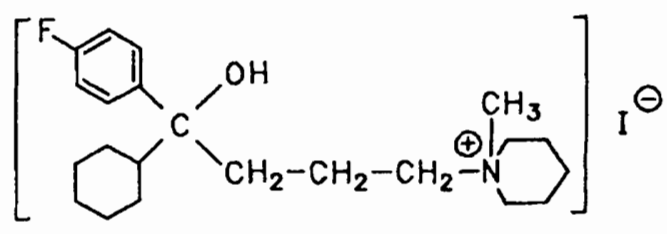

3

rated by fractional crystallization of their corresponding diastereomeric mandelates (for details see Experimental). $(R)-4$ and (S)-4 were obtained as crystalline compounds with high enantiomeric purity (see below). Their catalytic hydro- 
genation $(\mathrm{Pd} / \mathrm{C}$ contact) yielded the enantiomers $(R)-2 \mathrm{a}$ and $(S)-2 \mathrm{a}$ which were isolated as hydrochlorides $[(R)-2 \mathrm{a} \cdot \mathrm{HCl}$ and $(S)-2 \mathrm{a} \cdot \mathrm{HCl}]$. The methiodides $(R)-3$ and $(S)-3$ were prepared by quaternization of the corresponding free bases $(R)$-2a and $(S)-2 \mathrm{a}$ with methyl iodide.<smiles>O=C(c1ccc(F)cc1)C1CCCCC1</smiles>

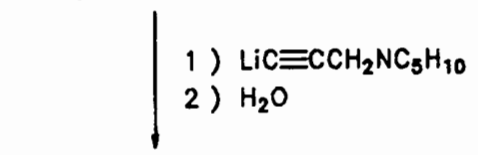<smiles>OC(C#CCN1CCCCC1)(c1ccc(F)cc1)C1CCCCC1</smiles>

$\operatorname{rac}-4$

resolution with $(R)$ - and

(S)-mandelic acid

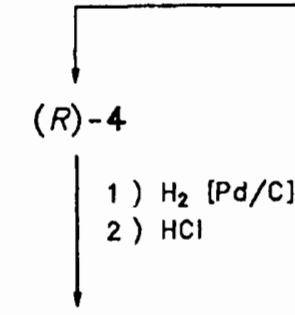

$(R)-2 a \cdot H C l$

1) $\mathrm{NaOH}$

2) $\mathrm{CH}_{3} \mathrm{I}$

$(R)-3$
$(S)-4$

1) $\mathrm{H}_{2}[\mathrm{Pd} / \mathrm{C}]$ 2) $\mathrm{HCl}$

$(S)-2 a \cdot H C l$

1) $\mathrm{NaOH}$

2) $\mathrm{CH}_{3} \mathrm{I}$

$(5)-3$
The enantiomeric purity of the optically active precursors $(R)-4$ and $(S)-4$ was determined by differential scanning calorimetry. For the purity determination a newly developed procedure ${ }^{4)}$ was used, which - in contrast to the "classical methods" - takes into account both calorimeter and substance properties and is thus capable of giving more accurate results (for details see Experimental). The data obtained from this calorimetric analysis are listed in Table 1, the phase diagram of the system $(R)-4 /(S)-4$ is shown in Figure 1. According to these data, the enantiomeric purity of $(R)-4$ and $(S)-4$ is $\geqslant 99.80$ and $\geqslant 99.94 \%$ e.e., respectively. As the catalytic hydrogenation of $(R)-4$ and $(S)-4$ and the subsequent reactions do not affect the enantiomeric purity (no reaction at the center of chirality), the same enantiomeric purities can be assumed for $(R)-2 \mathrm{a} \cdot \mathrm{HCl}$ and $(R)-3(\geqslant 99.8 \%$ e.e.) as well as for $(S)-2 \mathrm{a} \cdot \mathrm{HCl}$ and $(S)-3(\geqslant 99.9 \%$ e.e. $)$.
Table 1. Data for rac-4, $(R)-4$, and $(S)-4$ determined by calorimetry ${ }^{a)}$

\begin{tabular}{cccc} 
Compound & $\vartheta_{\text {fus }}\left[{ }^{\circ} \mathrm{C}\right]$ & $\begin{array}{c}\Delta_{\text {fus }} H^{\ominus} \\
{\left[\mathrm{kJmol}^{-1}\right]}\end{array}$ & $X[\mathrm{~mol}-\%]$ \\
\hline rac-4 & 135.9 & 46.4 & \\
$(R)-4$ & 150.1 & 46.2 & 99.90 \\
$(S)-4$ & 150.2 & 46.2 & 99.97 \\
\hline
\end{tabular}

a) $9_{\text {fus: }}$ melting temp.; $\Delta_{\text {fus }} H^{\ominus}$ : molar enthalpy of fusion of the racemate and the main component, respectively; $X$ : molar fraction of the main component.

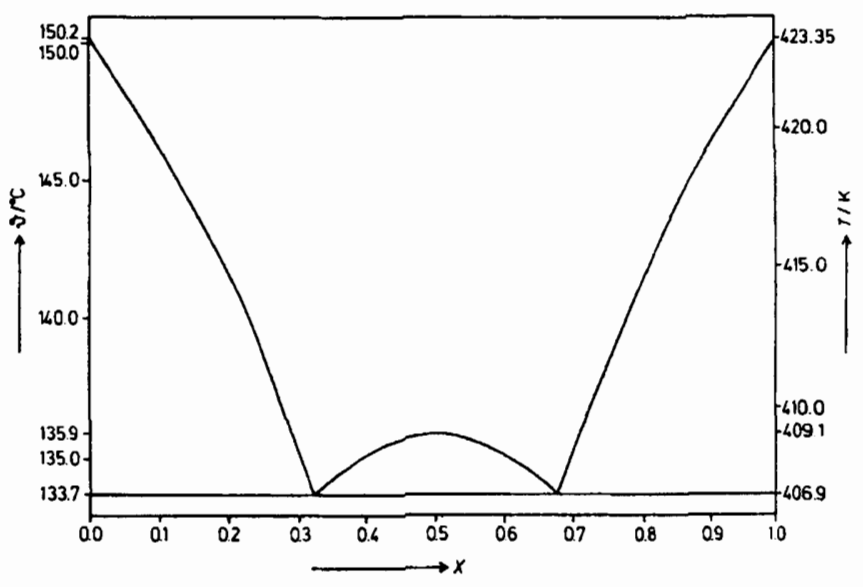

Figure 1. Phase diagram of the system $(R)-4 /(S)-4$

The absolute configuration of the enantiomers of $\mathbf{2 a}, \mathbf{3}$, and 4 was determined by an X-ray crystal-structure analysis of the laevorotatory methiodide 5 , which was prepared by quaternization of (-)-4 with methyl iodide (the signs of the optical rotations correspond to solutions of these compounds in $\mathrm{CHCl}_{3}$ ).<smiles>C[N+]1(C)CCCC1</smiles>

$(s)-5$

The structure of $(-)-5$ is depicted in Figure 2. Bond lengths and angles (Table 2) are mostly normal, except for some librationally shortened bond lengths at the extremes of the rings; the precision of light-atom dimensions in the presence of iodine is necessarily limited. The iodide ion forms a hydrogen bond to the hydroxy group [O … 352 , $\mathrm{H} \cdots \mathrm{I} 267 \mathrm{pm} ; \mathrm{O}-\mathrm{H} \cdots \mathrm{I} 172^{\circ}$ (I at $\frac{1}{2}+x, \frac{1}{2}-y, 1-z$ ). As can be seen from Figure 2, $(-)-5$ has $(S)$ configuration. Based on this result, the absolute configuration of the enantiomers of $2 \mathrm{a}, 3$, and 4 can also be assigned.

Both functional and receptor binding studies on muscarinic M1-M4 receptors revealed that $(R)$-p-fluoro-hexahydro-difenidol $[(R)-2 \mathrm{a}]$ was more potent than its antipode (S)-2a by up to two orders of magnitude ${ }^{2 c, 3 d)}$. The stereo- 


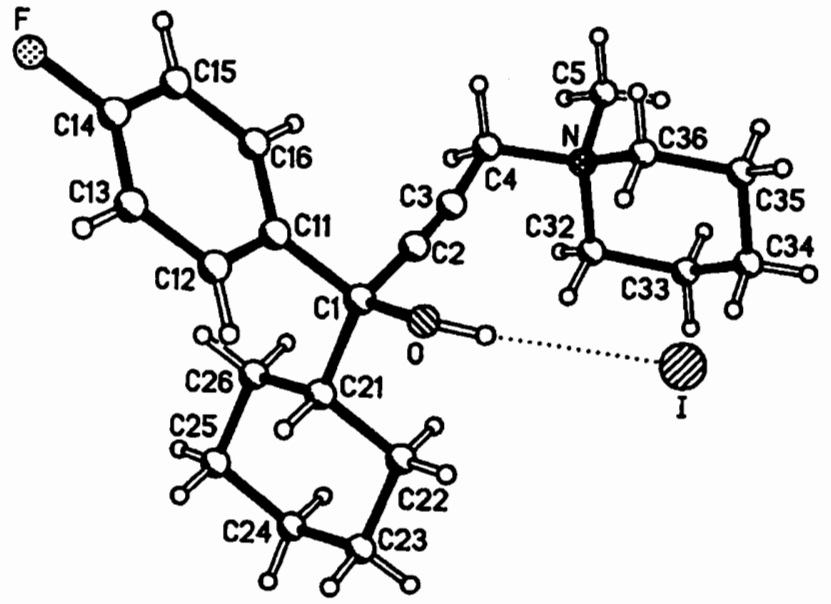

Figure 2. The structure of $(S)$-5 in the crystal, showing the atom numbering scheme; radii are arbitrary; the hydrogen bond is shown as a dotted line

Table 2. Selected bond lengths $[\mathrm{pm}]$ and angles $\left[{ }^{\circ}\right]$ for $(S)-5$

\begin{tabular}{|c|c|c|c|c|c|}
\hline $\begin{array}{l}F-C(14) \\
N-C(4) \\
N-C(32) \\
C(1)-C(2) \\
C(1)-C(21) \\
C(3)-C(4)\end{array}$ & $\begin{array}{l}135.8 \\
150.8 \\
150.8 \\
148.5 \\
154.5 \\
145.9\end{array}$ & $\begin{array}{l}(4) \\
(4) \\
(5) \\
(4) \\
(4) \\
(4)\end{array}$ & $\begin{array}{l}0-C(1) \\
N-C(5) \\
N-C(36) \\
C(1)-C(11) \\
C(2)-C(3)\end{array}$ & $\begin{array}{l}143.2 \\
149.8 \\
151.4 \\
152.3 \\
118.2\end{array}$ & $\begin{array}{l}(4) \\
(4) \\
(4) \\
(4) \\
(4)\end{array}$ \\
\hline $\begin{array}{l}C(4)-N-C(5) \\
C(5)-N-C(32) \\
C(5)-N-C(36) \\
O-C(1)-C(2) \\
C(2)-C(1)-C(11) \\
C(2)-C(1)-C(21) \\
C(1)-C(2)-C(3) \\
N-C(4)-C(3) \\
C(1)-C(11)-C(16 \\
F-C(14)-C(15) \\
C(1)-C(21)-C(26 \\
N-C(36)-C(35)\end{array}$ & & $\begin{array}{l}105.9(2) \\
111.1(3) \\
110.4(2) \\
110.1(2) \\
109.9(2) \\
109.6(3) \\
176.5(3) \\
114.7(2) \\
123.4(3) \\
118.7(3) \\
113.0(3) \\
112.3(3)\end{array}$ & $\begin{array}{l}C(4)-N-C(32) \\
C(4)-N-C(36) \\
C(32)-N-C(36) \\
0-C(1)-C(11) \\
O-C(1)-C(21) \\
C(11)-C(1)-C(21 \\
C(2)-C(3)-C(4) \\
C(1)-C(11)-C(12 \\
F-C(14)-C(13) \\
C(1)-C(21)-C(22 \\
N-C(32)-C(33)\end{array}$ & 1) & $\begin{array}{l}109.7(2) \\
109.1(2) \\
110.5(3) \\
105.3(2) \\
110.2(2) \\
111.7(2) \\
173.2(4) \\
118.8(3) \\
119.0(3) \\
112.8(2) \\
111.0(3)\end{array}$ \\
\hline
\end{tabular}

selectivity ratio $[(R)-2 \mathrm{a} /(S)-2 \mathrm{a}]$ varied, depending on the receptor subtype studied; it was lowest at M2 receptors (ca. 15). (S)-2a exhibited only weak receptor discriminatory properties, whereas $(R)$-2a showed a preference for M1, M3, and $M 4$ over $M 2$ receptors (about 16 -fold). The affinity profile of $(R)-2 \mathrm{a}(\mathrm{M} 1 \approx \mathrm{M} 3 \approx \mathrm{M} 4>\mathrm{M} 2)$ is very similar to that of $(R)$-hexahydro-difenidol $[(R)-1 \mathbf{a}]^{\text {?c.3c.3.7d) }}$, but different from that of rac-p-fluoro-hexahydro-sila-difenidol $(\mathrm{rac}-\mathbf{2} \mathbf{b})$ $(\mathrm{M} 3 \geqslant \mathrm{M} 4 \geqslant \mathrm{M} 1>\mathrm{M} 2)^{2 \mathrm{a}, 2 \mathrm{c})}$. $(R)-2 \mathrm{a}$ thus represents a useful tool to further characterize muscarinic receptor subtypes. As the stereoselectivity ratios $[(R)-2 \mathrm{a} /(S)-2 \mathrm{a}]$ depend on the receptor subtype studied $(\mathrm{M} 1 \geqslant \mathrm{M} 3 \geqslant \mathrm{M} 4>\mathrm{M} 2)$, these ratios can be used as an additional parameter to identify muscarinic receptor subtypes providing information that racemates cannot give ${ }^{2 b, 2 c, 3 b-d)}$.

$(R)$-p-Fluoro-hexahydro-difenidol methiodide $[(R)-3 \mathrm{a}]$ was also found to exhibit higher affinites (by up to two orders of magnitude) for M1-M4 receptors than its antipode (S)-3a, and both enantiomers displayed a small preference for M1 receptors ${ }^{2 c, 3 d)}$. However, the stereoselectivity ratios $[(R)-3 \mathrm{a} /(\mathrm{S})-3 \mathrm{a}]$ were very similar, regardless of the receptor subtype studied.

We thank the Deutsche Forschungsgemeinschaft and the Fonds der Chemischen Industrie for financial support.

\section{Experimental}

a) Syntheses

All reactions were performed in dried solvents under a dry nitrogen atmosphere unless stated otherwise. - Melting points were determined with a Kofler apparatus (Reichert) and are uncorrected. - ${ }^{1} \mathrm{H}$ NMR: Bruker AM-400 spectrometer, operating at $400.1 \mathrm{MHz}\left[\mathrm{CD}_{3} \mathrm{OD}\right.$ or $\mathrm{CDCl}_{3}$ as solvents, TMS as internal standard $(\delta=0)]$. $-{ }^{13} \mathrm{C}$ NMR: Bruker AM-400 spectrometer, operating at $100.6 \mathrm{MHz}\left[\mathrm{CD}_{3} \mathrm{OD}\right.$ or $\mathrm{CDCl}_{3}$ as solvents and internal standards $\left.\left(\mathrm{CD}_{3} \mathrm{OD}, \delta=49.0 ; \mathrm{CDCl}_{3}, \delta=77.05\right)\right]$. Assignment of the ${ }^{13} \mathrm{C}$-NMR data was supported by DEPT experiments. FAB MS: Finnigan-MAT-8430 spectrometer (glycerol as matrix, xenon as FAB source). - Optical rotations: Polarimeter 241, Perkin-Elmer. The solvent used for these measurements $\left(\mathrm{CHCl}_{3}\right.$, LiChrosolv ${ }^{\circledR}$; Merck) was additionally purified prior to use by $d y-$ namic drying over an $\mathrm{Al}_{2} \mathrm{O}_{3}$ (Merck) column.

(R)-1-Cyclohexyl-1-(4-fluorophenyl)-4-piperidino-1-butanol $\mathrm{Hy}$ drochloride [(R)-p-Fluoro-hexahydro-difenidol Hydrochloride] $[(R)-2 a \cdot H C l]: 75 \mathrm{mg}$ of a Pd/C contact (10\% Pd; Merck) was added to a solution of $(R)-4(2.10 \mathrm{~g}, 6.37 \mathrm{mmol})$ in methanol $(75 \mathrm{ml})$. The suspension was stirred at room temp. for $2 \mathrm{~h}$ under a hydrogen atmosphere (continuous $\mathrm{H}_{2}$ flow). The reaction mixture (complete conversion, monitored by ${ }^{1} \mathrm{H}$ NMR) was filtered and the filtrate concentrated in vacuo. After addition of a $0.5 \mathrm{M}$ solution of $\mathrm{HCl}$ in ether $(12.8 \mathrm{ml}, 6.4 \mathrm{mmol} \mathrm{HCl})$ to the oily residue, the solid crude product was isolated and purified by two recrystallizations from 2propanol/diethyl ether $(2: 1, \mathrm{v} / \mathrm{v})$ to give $1.93 \mathrm{~g}(82 \%)$ of colorless needles, m.p. $252^{\circ} \mathrm{C}$ (dec.), $[\alpha]_{586}^{27}=-29\left(c=0.5, \mathrm{CHCl}_{3}\right)$. ${ }^{1} \mathrm{H}$ NMR $\left(\mathrm{CD}_{3} \mathrm{OD}\right): \delta=0.9-1.3,1.3-1.6,1.6-2.1(\mathrm{~m}, 21 \mathrm{H}$, $\mathrm{C}_{6} \mathrm{H}_{11}, \mathrm{OCCH}_{2} \mathrm{CH}_{2} \mathrm{CH}_{2} \mathrm{~N}, \mathrm{CCH}_{2} \mathrm{C}$ of $\left.\mathrm{NC}_{5} \mathrm{H}_{10}\right) ; 2.7-2.9,2.9-3.1$, $3.3-3.5\left(\mathrm{~m}, 6 \mathrm{H}, \mathrm{CCH}_{2} \mathrm{~N}\right) ; 7.0-7.1,7.35-7.45\left(\mathrm{~m}, 4 \mathrm{H}, \mathrm{C}_{6} \mathrm{H}_{4} \mathrm{~F}\right)$. ${ }^{13} \mathrm{C}$ NMR ( $\left.\mathrm{CD}_{3} \mathrm{OD}\right): \delta=20.0,22.7,24.2(2 \mathrm{C}), 27.6,27.7,27.8$, $27.9,28.5$ (C-2 to $\mathrm{C}-6$ of $\mathrm{C}_{6} \mathrm{H}_{11}, \mathrm{C}-3$ to $\mathrm{C}-5$ of $\mathrm{NC}_{5} \mathrm{H}_{10}$, $\left.\mathrm{OCCH}_{2} \mathrm{CH}_{2} \mathrm{CH}_{2} \mathrm{~N}\right) ; 37.0\left(\mathrm{OCCH}_{2} \mathrm{CH}_{2} \mathrm{CH}_{2} \mathrm{~N}\right) ; 50.3\left(\mathrm{C}-1\right.$ of $\left.\mathrm{C}_{6} \mathrm{H}_{11}\right)$; $54.1(2 \mathrm{C}), 58.6\left(\mathrm{CCH}_{2} \mathrm{~N}\right) ; 79.3(\mathrm{COH}) ; 115.3(2 \mathrm{C})\left(\mathrm{d},{ }^{2} J_{\mathrm{CF}}=21.3 \mathrm{~Hz}\right.$, $\mathrm{C}-3$ and C-5 of $\left.\mathrm{C}_{6} \mathrm{H}_{4} \mathrm{~F}\right) ; 129.1(2 \mathrm{C})\left(\mathrm{d},{ }^{3} J_{\mathrm{CF}}=7.7 \mathrm{~Hz}, \mathrm{C}-2\right.$ and C6 of $\left.\mathrm{C}_{6} \mathrm{H}_{4} \mathrm{~F}\right) ; 142.0\left(\mathrm{~d},{ }^{4} J_{\mathrm{CF}}=3.1 \mathrm{~Hz}, \mathrm{C}-1\right.$ of $\left.\mathrm{C}_{6} \mathrm{H}_{4} \mathrm{~F}\right) ; 162.9\left(\mathrm{~d},{ }^{1} J_{\mathrm{CF}}=\right.$ $243.4 \mathrm{~Hz}, \mathrm{C}-4$ of $\left.\mathrm{C}_{6} \mathrm{H}_{4} \mathrm{~F}\right)$. - FAB MS: $m / z(\%)=334(100)$ [cation].

$$
\begin{array}{llll}
\mathrm{C}_{21} \mathrm{H}_{33} \text { ClFNO (369.9) } & \text { Calcd. C } 68.18 \text { H } 8.99 \text { N } 3.79 \\
& \text { Found C } 68.0 \text { H } 9.1 \quad \text { N } 3.7
\end{array}
$$

(S)-1-Cyclohexyl-1-(4-fluorophenyl)-4-piperidino-1-butanol Hydrochloride [(S)-p-Fluoro-hexahydro-difenidol Hydrochloride] $[(S)$ $2 \mathrm{a} \cdot \mathrm{HCl}]$ : Prepared by catalytic hydrogenation of $(S)-4$, analogously to the synthesis of $(R)-2 \mathrm{a} \cdot \mathrm{HCl}$; yield $78 \%$, colorless needles, mp. $252^{\circ} \mathrm{C}(\mathrm{dec}),[\alpha]_{886}^{27}=+29\left(c=0.5, \mathrm{CHCl}_{3}\right)$. For spectroscopic data see $(R)-2 \mathbf{a} \cdot \mathrm{HCl}$.

$$
\begin{array}{llll}
\mathrm{C}_{21} \mathrm{H}_{33} \mathrm{ClFNO}(369.9) & \text { Calcd. C } 68.18 \text { H } 8.99 & \text { N } 3.79 \\
& \text { Found C } 68.4 \quad \text { H } 9.2 & \text { N } 3.8
\end{array}
$$

(R)-1-Cyclohexyl-1-(4-fluorophenyl)-4-piperidino-1-butanol Methiodide [(R)-3]: Methyl iodide $(255 \mathrm{mg}, 1.8 \mathrm{mmol})$ was added to a solution of $(R)-2 \mathrm{a}(296 \mathrm{mg}, 0.89 \mathrm{mmol}$; obtained from $(R)-2 \mathrm{a}$. $\mathrm{HCl})$ in acetone $(15 \mathrm{ml})$, and the reaction mixture was stirred at $30^{\circ} \mathrm{C}$ for $3 \mathrm{~h}$. After evaporation of the solvent and the excess of methyl iodide, the solid residue was washed with pentane $(5 \mathrm{ml})$ and then purified by recrystallization from acetone/diethyl ether to give $331 \mathrm{mg}(78 \%)$ of colorless needles, m.p. $150^{\circ} \mathrm{C},[\alpha]_{586}^{27}=-13$ $\left(c=0.5, \mathrm{CHCl}_{3}\right)$. - ' $\mathrm{H}$ NMR $\left(\mathrm{CD}_{3} \mathrm{OD}\right): \delta=0.9-1.3,1.35-1.45$, $1.6-1.7,1.7-1.85,1.9-2.1\left(\mathrm{~m}, 21 \mathrm{H}, \mathrm{C}_{6} \mathrm{H}_{11}, \mathrm{OCCH}_{2} \mathrm{CH}_{2} \mathrm{CH}_{2} \mathrm{~N}\right.$, $\mathrm{CCH}_{2} \mathrm{C}$ of $\left.\mathrm{NC}_{5} \mathrm{H}_{10}\right) ; 2.94\left(\mathrm{~s}, 3 \mathrm{H}, \mathrm{NCH}_{3}\right) ; 3.2-3.3\left(\mathrm{~m}, 6 \mathrm{H}, \mathrm{CCH}_{2} \mathrm{~N}\right)$; 7.0-7.1, 7.4-7.5 (m, 4H, $\left.\mathrm{C}_{6} \mathrm{H}_{4} \mathrm{~F}\right) .-{ }^{13} \mathrm{C}$ NMR $\left(\mathrm{CD}_{3} \mathrm{OD}\right): \delta=$ 
$17.8,20.9(2 \mathrm{C}), 22.0,27.6,27.8(2 \mathrm{C}), 28.0,28.6\left(\mathrm{C}-2\right.$ to $\mathrm{C}-6$ of $\mathrm{C}_{6} \mathrm{H}_{11}$, C-3 to C-5 of $\left.\mathrm{NC}_{5} \mathrm{H}_{10}, \mathrm{OCCH}_{2} \mathrm{CH}_{2} \mathrm{CH}_{2} \mathrm{~N}\right) ; 36.5\left(\mathrm{OCCH}_{2} \mathrm{CH}_{2}\right.$ $\left.\mathrm{CH}_{2} \mathrm{~N}\right) ; 48.5\left(\mathrm{NCH}_{3}\right) ; 50.4\left(\mathrm{C}-1\right.$ of $\left.\mathrm{C}_{6} \mathrm{H}_{11}\right) ; 62.1(2 \mathrm{C})(\mathrm{C}-2$ and $\mathrm{C}-6$ of $\left.\mathrm{NC}_{5} \mathrm{H}_{10}\right) ; 64.6\left(\mathrm{OCCH}_{2} \mathrm{CH}_{2} \mathrm{CH}_{2} \mathrm{~N}\right) ; 79.4(\mathrm{COH}) ; 115.3$ (2C) (d, ${ }^{2} J_{\mathrm{CF}}=21.0 \mathrm{~Hz}, \mathrm{C}-3$ and $\mathrm{C}-5$ of $\left.\mathrm{C}_{6} \mathrm{H}_{4} \mathrm{~F}\right) ; 129.2(2 \mathrm{C})\left(\mathrm{d},{ }^{3} J_{\mathrm{CF}}=\right.$ $7.7 \mathrm{~Hz}, \mathrm{C}-2$ and $\mathrm{C}-6$ of $\left.\mathrm{C}_{6} \mathrm{H}_{4} \mathrm{~F}\right) ; 141.9\left(\mathrm{~d},{ }^{4} \mathrm{~J}_{\mathrm{CF}}=3.2 \mathrm{~Hz}, \mathrm{C}-1\right.$ of $\left.\mathrm{C}_{6} \mathrm{H}_{4} \mathrm{~F}\right) ; 162.9\left(\mathrm{~d},{ }^{1} J_{\mathrm{CF}}=243.4 \mathrm{~Hz}, \mathrm{C}-4\right.$ of $\left.\mathrm{C}_{6} \mathrm{H}_{4} \mathrm{~F}\right) .-\mathrm{FAB} \mathrm{MS}$ : $m / z(\%)=348(100)$ [cation].

$$
\begin{array}{llllll}
\mathrm{C}_{22} \mathrm{H}_{35} \text { FINO (475.4) } & \text { Calcd. C 55.58 } & \text { H } 7.42 & \text { N } 2.95 \\
& \text { Found C 54.8 } & \text { H } 7.7 & \text { N } 2.9
\end{array}
$$

(S)-1-Cyclohexyl-1-(4-fluorophenyl)-4-piperidino-1-butanol Methiodide [(S)-3]: Prepared by quaternization of $(S)-2$ a [obtained from $(S)-2 \mathrm{a} \cdot \mathrm{HCl}$ with methyl iodide, analogously to the synthesis of $(R)-3$; yield $84 \%$, colorless needles, m.p. $150^{\circ} \mathrm{C},[\alpha]_{586}^{27}=+13$ $\left(c=0.5, \mathrm{CHCl}_{3}\right)$. For spectroscopic data see $(R)-3$.

$$
\begin{array}{llllll}
\mathrm{C}_{22} \mathrm{H}_{35} \text { FINO (475.4) } & \text { Calcd. C } 55.58 \text { H } 7.42 & \text { N } 2.95 \\
& \text { Found C } 55.2 & \text { H } 7.6 & \text { N } 2.9
\end{array}
$$

rac-1-Cyclohexyl-1-(4-fluorophenyl)-4-piperidino-2-but yn-1-ol [rac-4]: A $1.6 \mathrm{M}$ solution of $n$-butyllithium in hexane $(62.5 \mathrm{ml}, 0.1$ $\mathrm{mol}$ of $n$-BuLi) was added dropwise at $-50^{\circ} \mathrm{C}$ to a stirred solution of 3-piperidino-1-propyne $(12.3 \mathrm{~g}, 0.1 \mathrm{~mol})$ in diethyl ether $(50 \mathrm{ml})$. After stirring at $-50^{\circ} \mathrm{C}$ for $2 \mathrm{~h}$, the reaction mixture was added dropwise within $30 \mathrm{~min}$ at $0^{\circ} \mathrm{C}$ to a stirred solution of cyclohexyl (4-fluorophenyl) ketone $(20.6 \mathrm{~g}, 0.1 \mathrm{~mol})$ in diethyl ether $(150 \mathrm{ml})$. After stirring for an additional period of $16 \mathrm{~h}$ at room temp., water $\left(75 \mathrm{ml}\right.$ ) was added at $0^{\circ} \mathrm{C}$ to the reaction mixture. The organic layer was separated and the aqueous layer extracted with diethyl ether. Thereafter, the combined organic extracts were washed with water and then dried with anhydrous $\mathrm{Na}_{2} \mathrm{SO}_{4}$. After evaporation of the solvent, the solid residue was purified by recrystallization from 2 . propanol to give $25.0 \mathrm{~g}(76 \%)$ of colorless crystals, m.p. $136^{\circ} \mathrm{C}$ (subl.). $-{ }^{1} \mathrm{H}$ NMR $\left(\mathrm{CDCl}_{3}\right): \delta=1.0-1.1,1.10-1.25,1.35-1.5$, $1.5-1.7,1.7-1.8,1.95-2.05\left(\mathrm{~m}, 17 \mathrm{H}, \mathrm{C}_{6} \mathrm{H}_{11}, \mathrm{CCH}_{2} \mathrm{C}\right.$ of $\left.\mathrm{NC}_{5} \mathrm{H}_{10}\right)$; $2.45-2.55\left(\mathrm{~m}, 4 \mathrm{H}, \mathrm{CCH}_{2} \mathrm{~N}\right.$ of $\left.\mathrm{NC}_{5} \mathrm{H}_{10}\right) ; 3.34\left(\mathrm{~s}, 2 \mathrm{H}, \mathrm{C} \equiv \mathrm{CCH}_{2} \mathrm{~N}\right)$; 3.7 ("s", $1 \mathrm{H}, \mathrm{COH})$; 6.95-7.05, 7.5-7.6 (m, 4H, $\left.\mathrm{C}_{6} \mathrm{H}_{4} \mathrm{~F}\right)$. ${ }^{13} \mathrm{C} \mathrm{NMR}\left(\mathrm{CDCl}_{3}\right): \delta=23.9,25.6(2 \mathrm{C}), 26.19,26.22,26.3,27.7,27.9$ (C-2 to C-6 of $\mathrm{C}_{6} \mathrm{H}_{11}, \mathrm{C}-3$ to $\mathrm{C}-5$ of $\left.\mathrm{NC}_{5} \mathrm{H}_{10}\right) ; 47.7\left(\mathrm{C} \equiv \mathrm{CCH}_{2} \mathrm{~N}\right)$; $50.2\left(\mathrm{C}-1\right.$ of $\left.\mathrm{C}_{6} \mathrm{H}_{11}\right) ; 53.0(2 \mathrm{C})\left(\mathrm{C}-2\right.$ and $\mathrm{C}-6$ of $\left.\mathrm{NC}_{5} \mathrm{H}_{10}\right) ; 76.0(\mathrm{COH})$; $81.8,87.1(\mathrm{C} \equiv \mathrm{C}) ; 114.4(2 \mathrm{C})\left(\mathrm{d},{ }^{2} J_{\mathrm{CF}}=21.3 \mathrm{~Hz}, \mathrm{C}-3\right.$ and $\mathrm{C}-5$ of $\left.\mathrm{C}_{6} \mathrm{H}_{4} \mathrm{~F}\right) ; 128.1(2 \mathrm{C})\left(\mathrm{d},{ }^{3} \mathrm{~J}_{\mathrm{Cr}}=7.8 \mathrm{~Hz}, \mathrm{C}-2\right.$ and C-6 of $\left.\mathrm{C}_{6} \mathrm{H}_{4} \mathrm{~F}\right) ; 140.2$ $\left(\mathrm{d},{ }^{4} J_{\mathrm{CH}}=2.1 \mathrm{~Hz}, \mathrm{C}-1\right.$ of $\left.\mathrm{C}_{6} \mathrm{H}_{4} \mathrm{~F}\right) ; 162.1$ (d. ${ }^{1} . J_{1 \%}=24.5 \mathrm{H} \% \mathrm{C}-4$ of $\left.\mathrm{C}_{6} \mathrm{H}_{4} \mathrm{~F}\right)$. - FAB MS: $m / z(\%)=330(100)\left[\mathrm{M}+\mathrm{H}^{+}\right]$.

$$
\mathrm{C}_{21} \mathrm{H}_{28} \text { FNO (329.5) Calcd. C } 76.56 \text { H } 8.57 \text { N } 4.25
$$

$$
\text { Found C } 76.5 \text { H } 8.7 \quad \text { N } 4.1
$$

(R)- and (S)-1-Cyclohexyl-1-(4-fluorophenyl)-4-piperidino-2-butyn-1-ol $[(R)$ - and $(S)-4]$ : A mixture of rac-4 $(7.4 \mathrm{~g}, 22.5 \mathrm{mmol})$ and $(S)$-mandelic acid $(3.5 \mathrm{~g}, 23 \mathrm{mmol})$ was dissolved in boiling acetonitrile $(150 \mathrm{ml})$. After filtration and cooling of the hot solution to room temp., seed crystals (obtained previously by spontaneous crystallization from an analogous reaction mixture, reduced scale) were added, and the reaction mixture was kept at $20^{\circ} \mathrm{C}$ for $24 \mathrm{~h}$ (no disturbance). The crystals obtained (ca. $4.2 \mathrm{~g}$ ) were isolated by filtration and then purified by three recrystallizations from acetonitrile [after dissolving the crystals $(1 \mathrm{~g})$ in hot acetonitrile $(30 \mathrm{ml})$, the solution was slowly cooled to room temp.]. Thereafter, a $0.1 \mathrm{M}$ aqueous $\mathrm{NaOH}$ solution $(200 \mathrm{ml})$ was added to the purified mandelate $(3.3 \mathrm{~g})$, and the liberated amine was isolated by extraction with diethyl ether. The ether solution was washed with water and then dried with anhydrous $\mathrm{Na}_{2} \mathrm{SO}_{4}$. After evaporation of the solvent, the solid residue was dried in vacuo and then purified by two recrystallizations from acetone to give $2.1 \mathrm{~g}[57 \%$, related to the portion of $(R)-4$ in rac-4] of $(R)-4$. (S)-4 was obtained from the combined mother liquors resulting from the crystallizations of $(R)$ $4 \cdot \mathrm{C}_{6} \mathrm{H}_{5} \mathrm{CH}(\mathrm{OH}) \mathrm{CO}_{2} \mathrm{H}$ from acetonitrile (see above): After evaporation of the acetonitrile, a $0.1 \mathrm{M}$ aqueous $\mathrm{NaOH}$ solution $(200 \mathrm{ml})$ and diethyl ether $(300 \mathrm{ml})$ were added to the solid residue. The ether layer was separated, washed with water, and dried with anhydrous $\mathrm{Na}_{2} \mathrm{SO}_{4}$. After evaporation of the solvent, the solid residue was dried in vacuo and recrystallized from acetone to give $4.5 \mathrm{~g}$ of colorless crystals, mainly consisting of $(S)-4$. This product and $(R)-$ mandelic acid $(2.1 \mathrm{~g}, 13.8 \mathrm{mmol})$ were dissolved in boiling acetonitrile (ca. $150 \mathrm{ml}$ ) and the resulting solution was kept at $20^{\circ} \mathrm{C}$ for $24 \mathrm{~h}$. The mandelate obtained was isolated by filtration, purified, and then transformed into $(S)-4$ analogously to the preparation of $(R)-4$ as described above; yield $1.85 \mathrm{~g}$ [50\%, related to the portion of $(S)-4$ in $r a c-4]$.

(R)-4: Colorless crystals, m.p. $150^{\circ} \mathrm{C},[\alpha]_{586}^{27}=+14(c=0.5$, $\mathrm{CHCl}_{3}$ ), enantiomeric purity $\geqslant 99.80 \%$ e.e. (see Table 1 ). For spectroscopic data see rac-4.

$$
\begin{array}{lllll}
\mathrm{C}_{21} \mathrm{H}_{28} \mathrm{FNO} \text { (329.5) } & \text { Calcd. C } 76.56 \text { H } 8.57 \text { N } 4.25 \\
& \text { Found C } 76.7 \text { H } 8.7 \text { N } 4.2
\end{array}
$$

(S)-4: Colorless crystals, m.p. $150^{\circ} \mathrm{C},[\alpha]_{586}^{27}=-14(c=0.5$, $\mathrm{CHCl}_{3}$ ), enantiomeric purity $\geqslant 99.94 \%$ e. e. (see Table 1). For spectroscopic data see rac-4.

$$
\begin{array}{lllll}
\mathrm{C}_{21} \mathrm{H}_{28} \mathrm{FNO}(329.5) & \text { Calcd. C } 76.56 & \text { H } 8.57 & \mathrm{~N} 4.25 \\
& \text { Found C } 76.4 & \text { H } 8.5 & \text { N } 4.3
\end{array}
$$

(S)-1-Cyclohexyl-1-(4-fluorophenyl)-4-piperidino-2-butyn-1-ol Methiodide $[(S)-5]$ : Prepared by quaternization of $(S)-4[(-)-4]$ with methyl iodide, analogously to the synthesis of $(R)-3$; yield $89 \%$, colorless needles, m.p. $190^{\circ} \mathrm{C}$ (dec.), $[\alpha]_{586}^{27}=-2(c=0.5$, $\left.\mathrm{CHCl}_{3}\right) .-{ }^{1} \mathrm{H} \mathrm{NMR}\left(\mathrm{CD}_{3} \mathrm{OD}\right): \delta=1.0-1.3,1.5-1.8,1.9-2.0(\mathrm{~m}$, $17 \mathrm{H}, \mathrm{C}_{6} \mathrm{H}_{11}, \mathrm{CCH}_{2} \mathrm{C}$ of $\left.\mathrm{NC}_{5} \mathrm{H}_{10}\right) ; 3.24\left(\mathrm{~s}, 3 \mathrm{H}, \mathrm{NCH}_{3}\right) ; 3.50-3.65(\mathrm{~m}$, $4 \mathrm{H}, \mathrm{CCH}_{2} \mathrm{~N}$ of $\mathrm{NC}_{5} \mathrm{H}_{10}$ ); 4.61 ("s", $2 \mathrm{H}, \mathrm{C} \equiv \mathrm{CCH}_{2} \mathrm{~N}$ ); 7.05-7.15, $7.50-7.65\left(\mathrm{~m}, 4 \mathrm{H}, \mathrm{C}_{6} \mathrm{H}_{4} \mathrm{~F}\right) .-{ }^{13} \mathrm{C} \mathrm{NMR}\left(\mathrm{CD}_{3} \mathrm{OD}\right): \delta=21.0(2 \mathrm{C})$, $21.9,27.2(2 \mathrm{C}), 27.4,28.7,29.0\left(\mathrm{C}-2\right.$ to $\mathrm{C}-6$ of $\mathrm{C}_{6} \mathrm{H}_{11}, \mathrm{C}-3$ to $\mathrm{C}-5$ of $\left.\mathrm{NC}_{5} \mathrm{H}_{10}\right) ; 49.5\left(\mathrm{NCH}_{3}\right) ; 51.3\left(\mathrm{C}-1\right.$ of $\left.\mathrm{C}_{6} \mathrm{H}_{11}\right) ; 54.9\left(\mathrm{C} \equiv \mathrm{CCH}_{2} \mathrm{~N}\right) ; 62.0$ (2C) $\left(\mathrm{C}-2\right.$ and $\mathrm{C}-6$ of $\left.\mathrm{NC}_{5} \mathrm{H}_{10}\right) ; 76.6(\mathrm{COH}) ; 74.3,96.1(\mathrm{C} \equiv \mathrm{C}) ; 115.5$ (2C) $\left(\mathrm{d},{ }^{2} J_{\mathrm{CF}}=21.5 \mathrm{~Hz}, \mathrm{C}-3\right.$ and C-5 of $\left.\mathrm{C}_{6} \mathrm{H}_{4} \mathrm{~F}\right) ; 129.2$ (2C) (d, ${ }^{3} J_{\mathrm{CF}}=8.1 \mathrm{~Hz}, \mathrm{C}-2$ and C-6 of $\left.\mathrm{C}_{6} \mathrm{H}_{4} \mathrm{~F}\right) ; 140.6\left(\mathrm{~d},{ }^{4} J_{\mathrm{CF}}=3.0 \mathrm{~Hz}\right.$, C-1 of $\left.\mathrm{C}_{6} \mathrm{H}_{4} \mathrm{~F}\right) ; 163.6\left(\mathrm{~d},{ }^{1} \mathrm{~J}_{\mathrm{CF}}=244.8 \mathrm{~Hz}, \mathrm{C}-4\right.$ of $\left.\mathrm{C}_{6} \mathrm{H}_{4} \mathrm{~F}\right) .-\mathrm{FAB}$ MS: $m / 2(\%)=344(100)$ [cation].

$$
\begin{array}{llll}
\mathrm{C}_{22} \mathrm{H}_{31} \mathrm{FINO}(471.4) & \text { Calcd. C } 56.06 \text { H } 6.63 \text { N } 2.97 \\
& \text { Found C } 56.1 \text { H } 6.6 \text { N } 2.9
\end{array}
$$

\section{b) Calorimetric Determination of Enantiomeric Purity}

Calorimeter: FP 84 DSC/TOA, Mettler Instruments $\mathrm{GmbH}$, Greifensee/Switzerland (heat-flux DSC). The calibration of the instrument, the experimental procedure, and the data evaluation (except for the determination of enantiomeric purity) followed the description in refs. ${ }^{5,6)}$. The results obtained from the calorimetric measurements are listed in Table 1. The uncertainty of the enthalpies was $\pm 2.5 \%$, of the temperatures $\pm 0.2 \mathrm{~K}$, and of the molar fraction of the impurities $\pm 50 \%$. The central part of the phase diagram (for rac-4 in the range between the two eutectic points) was calculated by the PRIGOGINE-DEFAY equation $\ln \left[4 x_{1}\left(1-x_{1}\right)\right]=$ $2 \Delta_{\text {fus }} H^{\ominus} / \mathbf{R}\left(1 / T_{\text {fus }}-1 / T\right)$ (see ref. $\left.{ }^{7}\right)$.

Calorimetric Purity Determination: Simulated DSC curves, based on calorimeter parameters, were compared with experimentally obtained DSC curves by variation of the given parameter (in this case "impurity concentration") until an optimal fit was obtained. To check the enantiomeric purities determined by this method, an additional measurement of $(S)-4$ was performed with a deliberate addition of $1 \mathrm{~mol}-\%$ of $(R)-4$. 


\section{c) Crystal-Structure Determination ${ }^{8)}$}

Crystal Data: $\mathrm{C}_{22} \mathrm{H}_{31}$ FINO (471.4); orthorhombic; space group $P 22_{1} 2_{1} ; a=726.2(3), b=1198.8(4), c=2548.6(10) \mathrm{pm} ; V=$ $2.219 \mathrm{~nm}^{3} ; Z=4 ; D_{\mathrm{x}}=1.41 \mathrm{Mg} \mathrm{m}^{-3} ; F(000)=960 ; \lambda\left(\right.$ Mo $\left.K_{\alpha}\right)=$ $71.069 \mathrm{pm} ; \mu=1.4 \mathrm{~mm}^{-1}$. Colorless prism $(0.9 \times 0.4 \times 0.15 \mathrm{~mm})$, grown by vapor diffusion of diethyl ether into a solution of $(-)-5$ in ethanol.

Data Collection and Reduction: A hemisphere of data $( \pm h$ $+k \pm l, 8198$ reflections, $2 \theta_{\max }=50^{\circ}$, monochromatized Mo- $K_{\alpha}$ radiation) were collected in an $\omega$-scan mode with a Siemens P3 four-circle diffractometer. Three check reflections decreased in intensity by ca. $7 \%$, and an appropriate correction was applied. An absorption correction based on $\psi$ scans gave transmission factors of $0.72-0.87$. Merging equivalent intensities yielded 3918 unique reflections $\left(R_{\text {int }}=0.018\right)$, of which 3539 with $F>4 \sigma(F)$ were used for all calculations (program system SHELX, modified by its author G. M. Sheldrick). The orientation matrix was refined from setting angles of 48 reflections in the range $2 \theta=20-24^{\circ}$.

Table 3. Atomic coordinates $\left(\times 10^{4}\right)$ and equivalent isotropic displacement parameters $\left(\times 10^{-1}\right)\left[\mathrm{pm}^{2}\right]$ for $(S)-5^{2)}$

\begin{tabular}{lclll}
\hline & $x$ & $y$ & $z$ & $U(e q)$ \\
\hline$I$ & $4850.2(3)$ & $1118.6(2)$ & $2524.8(1)$ & $57(1)$ \\
$\mathbf{F}$ & $1261(4)$ & $3517(2)$ & $4683(1)$ & $93(1)$ \\
$\mathrm{O}$ & $7512(3)$ & $4251(2)$ & $6280(1)$ & $55(1)$ \\
$\mathrm{N}$ & $4223(4)$ & $6218(2)$ & $7981(1)$ & $42(1)$ \\
$\mathrm{C}(1)$ & $6332(4)$ & $5176(3)$ & $6164(1)$ & $43(1)$ \\
$\mathrm{C}(2)$ & $5392(4)$ & $5560(3)$ & $6649(1)$ & $47(1)$ \\
$\mathrm{C}(3)$ & $4572(5)$ & $5890(3)$ & $7018(1)$ & $47(1)$ \\
$\mathrm{C}(4)$ & $3361(4)$ & $6248(3)$ & $7443(1)$ & $51(1)$ \\
$\mathrm{C}(5)$ & $2694(5)$ & $6450(3)$ & $8360(1)$ & $53(1)$ \\
$\mathrm{C}(11)$ & $4921(4)$ & $4727(2)$ & $5775(1)$ & $44(1)$ \\
$\mathrm{C}(12)$ & $5540(5)$ & $4206(3)$ & $5321(1)$ & $63(1)$ \\
$\mathrm{C}(13)$ & $4295(7)$ & $3781(3)$ & $4955(1)$ & $71(1)$ \\
$\mathrm{C}(14)$ & $2476(5)$ & $3895(3)$ & $5047(1)$ & $63(1)$ \\
$\mathrm{C}(15)$ & $1812(5)$ & $4374(4)$ & $5492(2)$ & $73(1)$ \\
$\mathrm{C}(16)$ & $3069(5)$ & $4789(3)$ & $5854(1)$ & $61(1)$ \\
$\mathrm{C}(21)$ & $7462(4)$ & $6145(3)$ & $5928(1)$ & $46(1)$ \\
$\mathrm{C}(22)$ & $8985(5)$ & $6558(3)$ & $6296(1)$ & $56(1)$ \\
$\mathrm{C}(23)$ & $10143(6)$ & $7440(3)$ & $6031(2)$ & $77(1)$ \\
$\mathrm{C}(24)$ & $8984(7)$ & $8410(4)$ & $5842(2)$ & $88(2)$ \\
$\mathrm{C}(25)$ & $7416(7)$ & $8022(4)$ & $5487(2)$ & $87(2)$ \\
$\mathrm{C}(26)$ & $6273(5)$ & $7118(3)$ & $5753(1)$ & $62(1)$ \\
$\mathrm{C}(32)$ & $5705(6)$ & $7095(3)$ & $8018(2)$ & $71(1)$ \\
$\mathrm{C}(33)$ & $6742(7)$ & $7009(5)$ & $8539(2)$ & $91(2)$ \\
$\mathrm{C}(34)$ & $7470(6)$ & $5836(5)$ & $8639(2)$ & $97(2)$ \\
$\mathrm{C}(35)$ & $5987(6)$ & $4988(4)$ & $8601(2)$ & $75(2)$ \\
$\mathrm{C}(36)$ & $5020(5)$ & $5069(3)$ & $8078(1)$ & $52(1)$ \\
\hline & & & &
\end{tabular}

a) $U(\mathrm{eq})$ defined as one third of the trace of the orthogonalized $U_{i j}$ tensor.

Structure Solution and Refinement: The structure was solved by direct methods and subjected to full-matrix least-squares refinement on $F$. Hydrogen atoms, all but two of which were located in difference syntheses, were included in the refinement using a riding model. The absolute configuration was determined by an $\eta$ refinement ${ }^{9}$; $\eta$ refined to $-1.06(5)$ for the original model, where- upon the structure was inverted for the final cycles. The final $R$ value was 0.027 , with $R_{w}=0.026$. The weighting scheme was $w^{-1}=\sigma^{2}(F)+0.00025 \cdot F^{2} .235$ parameters; $S=1.3$; max. $\Delta / \sigma=0.03 ; \max . \Delta \mathrm{Q}=0.6 \times 10^{-6} \mathrm{e} \mathrm{pm}^{-3}$. Final atomic coordinates are given in Table 3, selected bond lengths and angles in Table 2.

\section{CAS Registry Numbers}

$(R)-2 \mathrm{a}: 132723-85-4 /(R)-2 \mathrm{a} \cdot \mathrm{HCl}: 132723-86-9 /(S)-2 \mathrm{a}: 132723$ 86-5 / (S)-2a · HCl: 132723-81-0/(R)-3a: 132723-82-1 / (S)-3a: 132723-83-2 / (rac)-4: 127471-25-4 / (R)-4: 127413-19-8 / (S)-4 127413-20-1 / (S)-5: 132723-84-3 / 3-piperidino-1-propyne: 5799. 75-7 / cyclohexyl 4-fluorophenyl ketone: 85014-02-4

1) Chemistry: ${ }^{\text {1a) }}$ Synthesis of rac-1 b: R. Tacke, H. Linoh, H. Zilch, J. Wess, U. Moser, E. Mutschler, G. Lambrecht, Liebigs Ann. Chem. 1985, 2223. - ${ }^{16)}$ rac-2b can be synthesized by analogy to rac-1 b; R. Tacke, K. Mahner, C. Strohmann, B. Forth, G. Lambrecht, E. Mutschler, unpublished results.

2) Pharmacology: ${ }^{2 a)}$ G. Lambrecht, R. Feifel, M. Wagner-Röder, C. Strohmann, H. Zilch, R. Tacke, M. Waelbroeck, J. Christophe, H. Boddeke, E. Mutschler, Eur. J. Pharmacol. 168 (1989) 71. ${ }^{2 b)}$ G. Lambrecht, R. Feifel, U. Moser, M. Wagner-Röder, L. K Choo, J. Camus, M. Tastenoy, M. Waelbroeck, C. Strohmann, R. Tacke, J. Rodrigues de Miranda, J. Christophe, E. Mutschler, Trends Pharmacol. Sci. (Suppl.) 10 (1989) 60. - 2c) M. Waelbroeck, J. Camus, M. Tastenoy, E. Mutschler, C. Strohmann, R Tacke, G. Lambrecht, J. Christophe, Eur. J. Pharmacol., Mol. Pharmacol. Sect., in press.

3) 3a) R. Tacke, C. Strohmann, S. Sarge, H. K. Cammenga, D. Schomburg, E. Mutschler, G. Lambrecht, Liebigs Ann. Chem 1988, 137. - ${ }^{36)}$ M. Waelbroeck, M. Tastenoy, J. Camus, R. Feifel, E. Mutschler, C. Strohmann, R. Tacke, G. Lambrecht, J. Christophe, Trends Pharmacol. Sci. (Suppl.) 10 (1989) 65. ${ }^{3 c)}$ R. Feifel, M. Wagner-Röder, C. Strohmann, R. Tacke, M. Waelbroeck, J. Christophe, E. Mutschler, G. Lambrecht, $B r$. $J$. Pharmacol. 99 (1990) 455. - ${ }^{3 d)}$ G. Lambrecht, T. P. Friebe, R. Feifel, N. Rettenmayr, M. Wagner-Röder, C. Strohmann, R. Tacke, E. Mutschler, Arch. Pharm. (Weinheim) 323 (1990) 790. - ${ }^{3 e)}$ M. Waelbroeck, J. Camus, M. Tastenoy, E. Mutschler, C. Strohmann, R. Tacke, G. Lambrecht, J. Christophe, Chirality, in press.

4) 4a) S. Sarge, S. Bauerecker, H. K. Cammenga, Thermochim. Acta 129 (1988) 309. - ${ }^{46)}$ S. Bauerecker, S. Sarge, H. K. Cammenga J. Therm. Anal. 35 (1989) 527.

5) R. Tacke, H. Linoh, L. Ernst, U. Moser, E. Mutschler, S. Sarge, H. K. Cammenga, G. Lambrecht, Chem. Ber. 120 (1987) 1229.

${ }^{6)}$ S. Sarge, H. K. Cammenga. Thermochim. Acta 94 (1985) 17.

7) J. Jacques, A. Collet, S. H. Wilen, Enantiomers, Racemates, and Resolutions, pp. 88-90, John Wiley \& Sons, New York 1981.

8) Further details of the structure investigation (complete bond lengths and angles, torsion angles, hydrogen atom coordinates, structure factors, temperature factors) are available on request from the Fachinformationszentrum Karlsruhe, Gesellschaft für wissenschaftlich-technische Information mbH, D-7514 Eggenstein-Leopoldshafen 2, Federal Republic of Germany, on quoting the depository number CSD-55047, the names of the authors, and the journal citation.

9) D. Rogers, Acta Crystallogr., Sect. A, 37 (1981) 734.

$[245 / 90]$ 